\title{
Improvement in mild anti-IgLON5 encephalopathy without immunotherapy: a case report
}

\author{
Yuting Wang, Xiuling Wu and Baoquan Lu*
}

\begin{abstract}
Background: Anti-lgLON5 antibody-related encephalopathy is a recently discovered and rare autoimmune disease, and its diagnosis and treatment are more challenging than for other autoimmune encephalopathic diseases. Sleep disorder is the most prominent symptom of the disease. It can also present with gait instability, dysarthria, dysphagia, dementia, ataxia, autonomic nervous system dysfunction, chorea, vertical gaze paralysis, and other symptoms. Immunotherapy remains the primary treatment for this disease; however, there is no definitive conclusion regarding the effect of immunotherapy. The clinical symptoms of the reported cases of anti-lgLON5 antibody-related encephalopathy were generally severe. However, the symptoms in our patient were mild and relieved without immunotherapy, unlike the previously reported cases.
\end{abstract}

Case presentation: A 62-year-old man presented with behavioural abnormalities and involuntary movements after nearly 2 months of fever and headache. He also had symptoms of mild sleep disorder. Due to the abnormal levels of infection-related indicators, antiviral treatment was started on the day of admission. The serum analysis confirmed the presence of IgLON5 antibody, and the patient was found to be genetically susceptible. The patient's symptoms resolved rapidly without immunotherapy and did not recur.

Conclusions: This case demonstrated that IgLON5 antibody-related encephalopathy might have mild manifestations. Infection and a genetic predisposition may be important causes for the disease. Patients with a mild disease may have a better prognosis.

Keywords: Anti-IgLON5 encephalopathy, Immunotherapy, Infection, Antiviral, Case report

\section{Background}

Anti-IgLON5 antibody-related encephalopathy is an exceedingly rare autoimmune disease of the central nervous system. The number of cases reported worldwide is limited, and all reported cases had severe clinical symptoms requiring immunotherapy. We report a case of mild anti-IgLON5 antibody-related encephalopathy and its remission without the use of immunotherapy. This case is an unusual presentation of the disease.

\footnotetext{
*Correspondence: lubaoquan2011@163.com

Department of Neurology, Tangshan Gongren Hospital, 27 Wenhua Road, Tangshan 063000, Hebei, People's Republic of China
}

\section{Case presentation}

A 62-year-old man presented with a 2-month history of intermittent fever and persistent headache. His medical history was unremarkable. According to his wife, he occasionally exhibited increased movement and vocalised during sleep. He was treated at a local hospital and showed no improvement. He was transferred to our neurology clinic for the treatment of worsening behavioural abnormalities such as unintelligible speech, incorrect answers to questions, inability to communicate with others, failure to recognise his family members, and irritability. The patient also had an episode of urination into his slippers 1 day before admission.

(c) The Author(s). 2021 Open Access This article is licensed under a Creative Commons Attribution 4.0 International License, which permits use, sharing, adaptation, distribution and reproduction in any medium or format, as long as you give appropriate credit to the original author(s) and the source, provide a link to the Creative Commons licence, and indicate if changes were made. The images or other third party material in this article are included in the article's Creative Commons licence, unless indicated otherwise in a credit line to the material. If material is not included in the article's Creative Commons licence and your intended use is not permitted by statutory regulation or exceeds the permitted use, you will need to obtain permission directly from the copyright holder. To view a copy of this licence, visit http://creativecommons.org/licenses/by/4.0/ The Creative Commons Public Domain Dedication waiver (http://creativecommons.org/publicdomain/zero/1.0/) applies to the data made available in this article, unless otherwise stated in a credit line to the data. 
On initial examination, the patient showed aggressive behaviour and agitation, which was mainly verbal, such as swearing. He did not indulge in any obvious physical attack but refused to be touched. He urinated once every $30 \mathrm{~min}$, and the volume of urine each time was approximately $50 \mathrm{~mL}$. Physical examination 1 day after admission: the patient had cognitive decline, characterised by poor orientation, calculation, and memory, and could only answer simple questions such as his name, and he refused to eat. His temperature was $38.2^{\circ} \mathrm{C}$. Cranial nerve examination showed no abnormality, the muscle strength of the limbs was normal, and the pathological signs were negative. During the physical examination and communication with the patient, involuntary movements of both upper limbs were observed.

Routine laboratory tests results showed a C-reactive protein level of $13.15 \mathrm{mg} / \mathrm{L}$ (normal, $0-5 \mathrm{mg} / \mathrm{L}$ ), erythrocyte sedimentation rate of $40 \mathrm{~mm} / \mathrm{h}$ (normal, $0-20 \mathrm{~mm} /$ h), lymphocyte ratio of 0.12 (normal, 0.20-0.40), and procalcitonin level of $0.19 \mathrm{ng} / \mathrm{mL}$ (normal, 0-0.05 ng/ $\mathrm{mL}$ ). Routine urinalysis and computed tomography of the lung showed no abnormalities. Electroencephalography showed a basic rhythm of 8 cycles/s and poor alpha wave formation in the right occipital area. Results of magnetic resonance imaging of the brain were unremarkable.

Based on the symptoms such as fever, sudden behavioural abnormalities, and abnormal indices indicative of infection, we considered the possibility of viral encephalitis and initiated antiviral therapy with acyclovir $0.5 \mathrm{~g}$ every $8 \mathrm{~h}$ intravenously guttae for 19 days $(20 \mathrm{mg} / \mathrm{kg} / \mathrm{d})$ on the day of admission. The behavioural abnormalities ceased 3 days later. During the first 2 days of admission, the patient exhibited involuntary and abnormal movements similar to actions such as knitting, hitting, and picking up or sorting objects. These movements were seen during sleep, wakefulness, and even when communicating with others.

On day 6, lumbar puncture results showed cerebrospinal fluid (CSF) pressure of $326 \mathrm{~mm} \mathrm{H}_{2} \mathrm{O}$ (normal, 80- $\left.180 \mathrm{~mm} \mathrm{H}_{2} \mathrm{O}\right)$. CSF examination revealed an elevated protein level $(0.96 \mathrm{~g} / \mathrm{L}$; normal, $0.12-0.6 \mathrm{~g} / \mathrm{L})$ and leukocyte counts $(34 / \mu \mathrm{L}$; normal, $\leq 5 / \mu \mathrm{L})$ with monocytic predominance. Due to the atypical symptoms, the presence of autoimmune encephalitis-related antibodies was investigated. Autoantibody screening using an in-house assay (KingMed Diagnostics Reference Laboratory, Guangzhou, Guangdong, China) showed the presence of IgLON5 IgG antibodies (1:30) in the serum but not in the CSF. Cell-based assay was used to detect the antiIgLON5 antibodies, as shown in Fig. 1. IgG4 and IgM were further identified by cell-based methods to determine the IgG antibody subclasses. Paraneoplastic antibodies were not present. Viral antibody testing was negative on two occasions (including enterovirus EV nucleic acid, adenovirus nucleic acid, cytomegalovirus nucleic acid, herpes simplex virus type I nucleic acid, herpes simplex virus type II nucleic acid, EB virus nucleic acid, enterovirus 71 nucleic acid, Coxsackie virus nucleic acid, Japanese encephalitis virus nucleic acid, varicella herpesvirus nucleic acid, rubella virus nucleic acid). With the administration of antiviral therapy alone (i.e., without immunotherapy), his sleep normalised, and his condition steadily improved.

A repeat lumbar puncture on day 14 indicated a normal CSF pressure of $143 \mathrm{~mm} \mathrm{H}_{2} \mathrm{O}$. CSF parameters had also improved, with a protein level of $0.61 \mathrm{~g} / \mathrm{L}$ and a leukocyte count of $10 / \mu \mathrm{L}$. The serum anti-IgLON5 antibody titre decreased to $1: 10$ and it was negative in the CSF, as shown in Fig. 1. Human leukocyte antigen (HLA) typing revealed HLA-DQB1*05:01 and HLADRB1*10:01 alleles. The patient was followed up for nearly 6 months and showed no recurrent pain or sleep disruptions. The clinical course and treatment schedule are shown in Fig. 2.

\section{Discussion and conclusions}

Sleep disorder is the most prominent symptom of antiIgLON5 antibody-related encephalopathy [1]. However, in this case, although there was a sleep disorder, it was
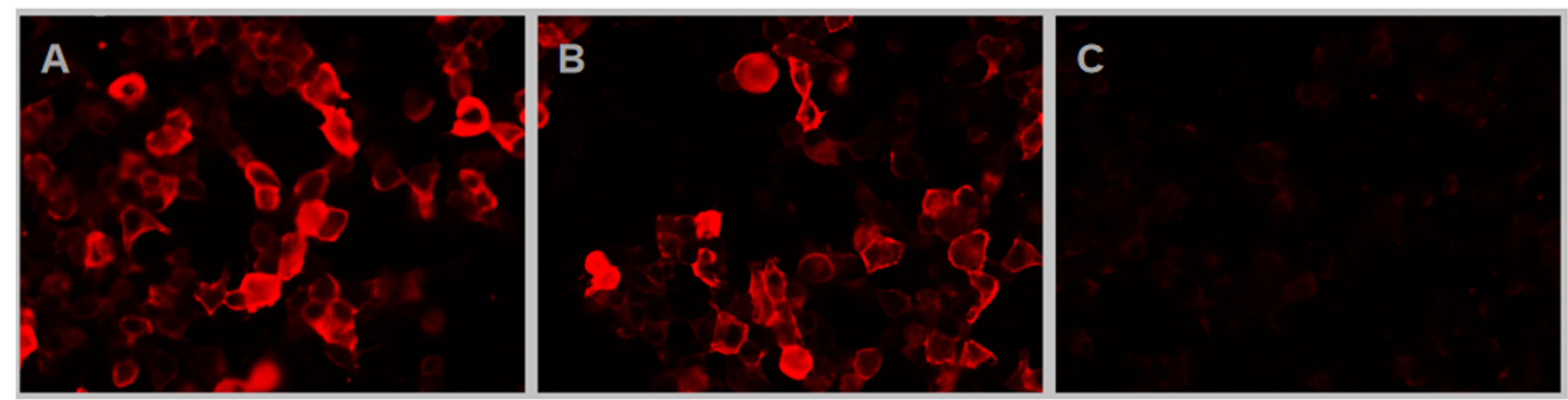

Fig. 1 IgLON5 antibody cell-based assay. ${ }^{a}$ Supplement: a IgLON5 IgG antibodies 1:30 in the serum. b IgLON5 IgG antibodies 1:10 in the serum. c IgLON5 IgG antibodies negative in the CSF 


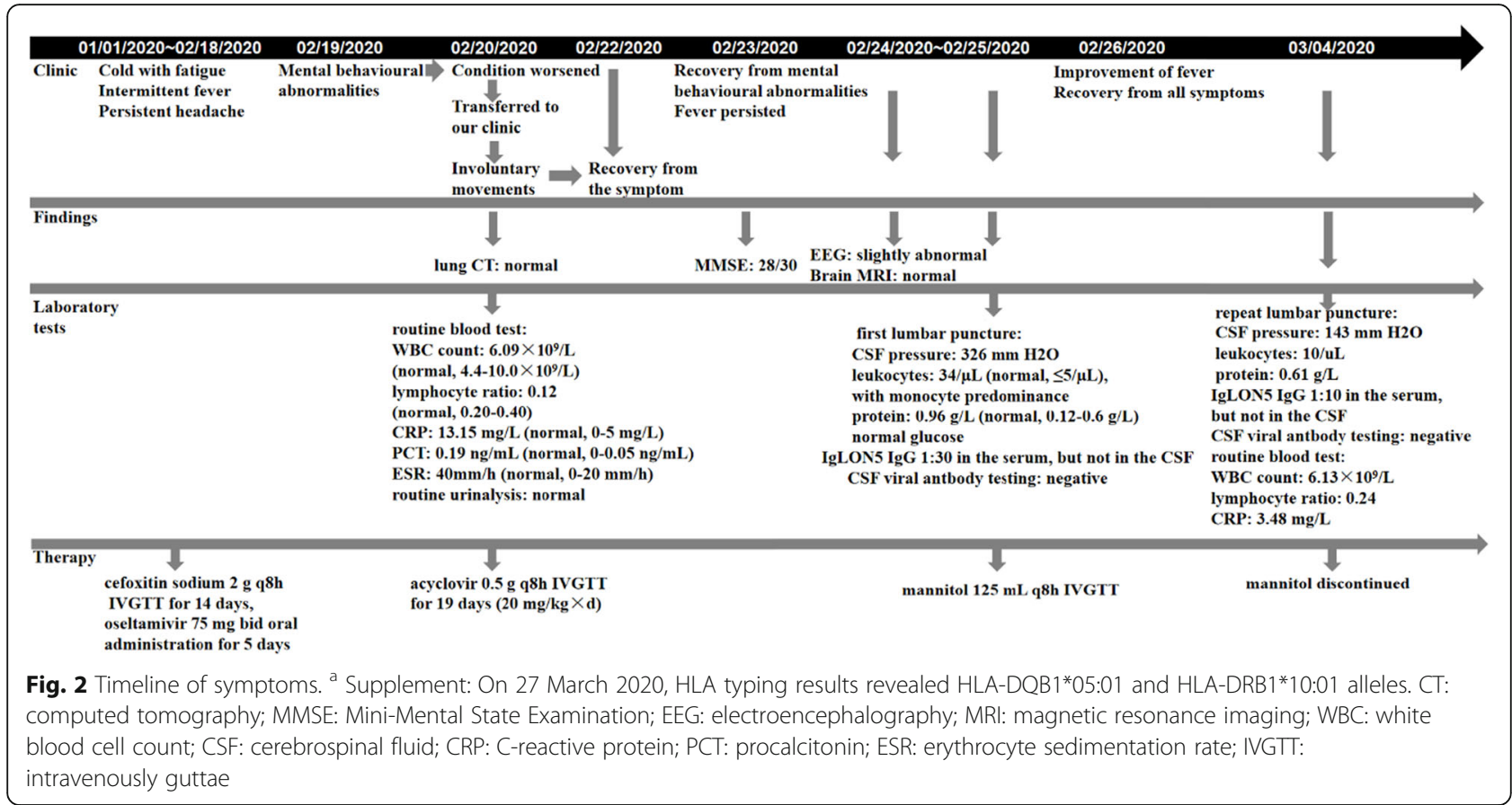

not very obvious. Unfortunately, polysomnography was not performed due to the limitation of hospital medical conditions. A simple portable sleep monitoring device was used to monitor the patient, including the nasal airflow, chest and abdominal breathing, blood oxygen saturation, and electrocardiogram parameters. The results showed that the patients had no obvious hypoxemia and sleep apnoea. This patient's signs and symptoms were consistent with 'cognitive impairment associated with chorea' [2]. However, the clinical presentation was mild, and his condition rapidly improved. This may explain why the IgLON5 antibody was positive only in the serum, and the titre was low.

Immunotherapy is the primary treatment for autoimmune encephalopathy; however, its efficacy remains uncertain. Our patient had a fever and abnormal infection indices. Despite two negative viral antibody tests, the possibility of viral infection was still considered. On initiating antiviral treatment, his clinical symptoms and laboratory results improved promptly and dramatically, and the titre of serum IgLON5 antibody also decreased. Based on clinical practice, we presume that IgLON5 antibody may be produced in viral infections in genetically susceptible individuals and may regress spontaneously with the resolution of viral encephalitis. Recent studies have shown that viral encephalitis (VE) can cause autoimmune encephalitis (AE). Among them, HSV encephalitis can cause anti-NMDAR encephalitis, which has been confirmed by many studies $[3,4]$. There are mainly three hypotheses about anti-NMDAR encephalitis induced by HSV encephalitis $[5,6]$ : molecular simulation, virus infection leading to inflammatory damage of the blood-brain barrier and neuronal damage, and necrosis, which leads to exposure and release of antigen determinants as autoimmune targets. Inflammation of the central nervous system in the course of infection causes immune activation. We speculate that the relationship between virus infection and anti-IgLON5 encephalopathy may also be related to the above hypothesis.

In this report, we discussed the aetiology, clinical manifestations, treatment, and prognosis of IgLON5 antibody-related encephalopathy and proposed a pathophysiological hypothesis. Infection and genetic predisposition may be important disease contributors, and patients with a mild disease may demonstrate a better prognosis.

\section{Abbreviations \\ CRP: C-reactive protein; CSF: Cerebrospinal fluid;; ESR: Erythrocyte sedimentation rate; HLA: Human leukocyte antigen; PCT: Procalcitonin; VE: Viral encephalitis; AE: Autoimmune encephalitis}

\section{Acknowledgements}

Not applicable.

\section{Authors' contributions}

YW drafted the manuscript. XW collected the case information and followed up with the patient. BL revised the manuscript for intellectual content. All authors have read and approved the final version of the manuscript.

Funding

This study was not funded.

Availability of data and materials

All data generated or analysed during this study are included in this published article. 


\section{Declarations}

\section{Ethics approval and consent to participate}

Informed consent was obtained from the patient to publish his case, and approval for this study was provided by the Research Ethics Committee of Tangshan Gongren Hospital.

\section{Consent for publication}

Written informed consent was obtained from the patient for publication of this case and any accompanying images. This report does not contain any personal information that could lead to the identification of the patient.

\section{Competing interests}

The authors declare that they have no competing interests.

Received: 27 November 2020 Accepted: 8 March 2021

Published online: 17 March 2021

\section{References}

1. Simabukuro MM, Sabater L, Adoni T, Cury RG, Haddad MS, Moreira CH, et al. Sleep disorder, chorea, and dementia associated with IgLON5 antibodies. Neurol Neuroimmunol Neuroinflamm. 2015;2:e136.

2. Gaig C, Graus F, Compta Y, Hogl B, Bataller L, Bruggemann N, et al. Clinical manifestations of the anti-IgLON5 disease. Neurology. 2017;88:1736-43.

3. Leypoldt F, Titulaer MJ, Aguilar E, Walther J, Bönstrup M, Havemeister S, et al. Herpes simplex virus-1 encephalitis can trigger anti-NMDA receptor encephalitis: case report. Neurology. 2013;81:1637-9.

4. Bektaş Ö, Tanyel T, Kocabaş BA, Fitöz S, Ince E, Deda G. Anti-N-methyl-Daspartate receptor encephalitis that developed after herpes encephalitis: a case report and literature review. Neuropediatrics. 2014;45:396-401.

5. Bradshaw MJ, Venkatesan A. Herpes simplex Virus-1 encephalitis in adults: pathophysiology, diagnosis, and management. Neurotherapeutics. 2016;13: 493-508.

6. Gelfand JM. Autoimmune encephalitis after herpes simplex encephalitis: insights into pathogenesis. Lancet Neurol. 2018;17:733-5.

\section{Publisher's Note}

Springer Nature remains neutral with regard to jurisdictional claims in published maps and institutional affiliations.

- fast, convenient online submission

- thorough peer review by experienced researchers in your field

- rapid publication on acceptance

- support for research data, including large and complex data types

- gold Open Access which fosters wider collaboration and increased citations

- maximum visibility for your research: over $100 \mathrm{M}$ website views per year

At $\mathrm{BMC}$, research is always in progress. 